\title{
Changes in Some Nutritional and Mineral Components of Nerica Rice Varieties as Affected by Field Application with Mycorrhiza and Chemical Fertilizer in Northern Cameroon
}

\author{
Maurice Gandebe ${ }^{1}$, Albert Ngakou ${ }^{2 *}$, Robert Ndjouenkeu ${ }^{3}$ \\ ${ }^{1}$ Institute of Research for Agricultural Development (IRAD), Ngaoundere, Cameroon \\ ${ }^{2}$ Faculty of Science, University of Ngaoundere, Ngaoundere, Cameroon \\ ${ }^{3}$ National High School of Agro-Industrial Sciences, University of Ngaoundere, Ngaoundere, Cameroon \\ Email: *alngakou@yahoo.fr
}

How to cite this paper: Gandebe, M., Ngakou, A. and Ndjouenkeu, R. (2017) Changes in Some Nutritional and Mineral Components of Nerica Rice Varieties as Affected by Field Application with Mycorrhiza and Chemical Fertilizer in Northern Cameroon. Food and Nutrition Sciences, 8 , 823-839.

https://doi.org/10.4236/fns.2017.88059

Received: July 14, 2017

Accepted: August 21, 2017

Published: August 24, 2017

Copyright $\odot 2017$ by authors and Scientific Research Publishing Inc. This work is licensed under the Creative Commons Attribution International License (CC BY 4.0).

http://creativecommons.org/licenses/by/4.0/

\section{(c) (i) Open Access}

\begin{abstract}
Rice as staple food is the most important and valuable cereal crop in Cameroon, particularly in rural areas where poor population cannot afford to cook and eat at their convenience. With the outbreak of Nerica varieties, it is important to evaluate and compare their nutritional and mineral properties to those of the local ones prior to their vulgarisation. Therefore, some nutritional and mineral properties of 4 Nerica and a local seeds varieties used in this study were harvested from control (T0), chemical fertilizer (TE), mycorrhiza (TM) applied plants, or their mixture (TEM). These seeds originating from Wakwa and/or Yagoua experimental sites were assessed and compared in a split-plot design $(4 \times 5) \times 3$ between treatment $(4)$ and varieties $(5)$. The local DIR-95 variety had values close to those of Nerica varieties in all the parameters assessed. Protein contents ranged from $17.66 \%-24.35 \%$, and was higher than those reported in rice samples elsewhere. All the studied varieties were classified as high amylose rice, and therefore, their textures in cooked form should be less sticky and harder, which is convenient to the diet behavior of many consumers. The relative low Fe content in Nerica rice suggest that these varieties may be resistant to $\mathrm{Fe}$ accumulation in seeds. The $\mathrm{P}, \mathrm{N}, \mathrm{Mg}$ contents were found to be more elevated in seeds harvested from mycorrhiza or chemical fertilizer applied plants, with Nerica seeds variety FKR62-N as the best of all in nutrients mineral and nutritional compositions. These results confirm varietal and site influences on proximate and mineral contents in the studied rice varieties.
\end{abstract}




\section{Keywords}

Nerica Rice, Mycorrhiza, Nutritional Properties, Mineral Contents, Chemical Fertilizer

\section{Introduction}

Rice (Oryza sp.) is the staple food source for half of the world population, making a major cereal crop [1]. It belongs to the family of graminaceae, the botanical genus Oryza, and comprises a total of 23 species of which only two are cultivated: Oryza sativa and Oryza glaberrima originated respectively from Asia and West Africa. Nerica, which means New Rice for Africa, is an interspecific hybrid resulting from crossing between the Asiatic rice (Oryza sativa) and the exotic African rice (Oryza glaberrima). These hybrids are known to exhibit better agronomic performances and high protein content compared to their parents [2]. These advantages could significantly contribute to alleviate the food insecurity and improve the nutrition of population of our different developing countries. Production of rice in sub-sahara African countries is constrained by abiotic and biotic factors, the availability of water and nutrients remaining the major limiting factors. Hence, Nerica varieties were introduced in a bit to show promising yield potentials in marginal soils compared to existing local varieties [3]. To sustainably achieve this yield potential, application of Arbuscular Mycorrhiza Fungi (AMF) is necessary. The most significant outcome of AMF, which is a symbiotic association between plant roots and a fungus [4], has been reported as the improvement of nutrient uptake by the host plant [5], and the modification of water status in water deficient plants [6] [7].

The nutritional, ecological and economical focuses on rice are of great importance: cardio-vascular and infant diseases due to excess or deficiency in food diet in oligo-elements and macro-nutriments are widely spread in Asia and Africa, and particularly in non-irrigated rice growing areas; the deficiency in iron is common due to anemia that mostly affects pregnant women and children ingesting high quantity of this cereal. Any improvement of rice grain quality in macro-nutriments and oligo-elements content could then help reducing the severity of nutritional problems. In African countries, demographic explosion invites researchers to think of long terms solutions for a sustainable production strategy of competitive rice grain quality without affecting the environment. Although a more efficient solution could be the diversification of food diets or their improvement with green legumes and meat, their access is never evident to farmers with low income due to the high cost in the market. Moreover, intensive input of inorganic fertilizers degrades the environment, causing water pollution and soil contamination through phytotoxicity, ammonia volatilization and nitrate accumulation [8]. Biological agriculture technics seem to be appropriate and adapted as low cost and environmental friendly strategy to be mastered by 
farmers. One of these strategies which is the use of mycorrhizal biofertilizers has been reported to improve cowpea [9], and rice [10] growth and yield.

In addition, the predominant component present in the endosperm or inner part of rice kernel is carbohydrate, and consists of $85 \%$ - $90 \%$ of starch, $2 \%$ pentose and $1 \%$ sugars [11]. Different rice varieties may have different unique texture after cooking, linked to their main constituent which is starch, and that governs the final texture of cooked rice. The starch fraction is made up of amylose and amylopectin that determines the cooking quality of rice [12] [13]. Thus, starch characteristics determine the amylose content and gelatinization temperature [14] [15]. Rice varieties with amylose content below 6\% remain sticky following cooking [16]. According to the same author, some consumers would prefer non sticky rice varieties which have higher amylose content of between 25\% - 30\%. Apart from starch, protein is the second most abundant component in rice, and its quality is high compared to other protein sources. The average protein content is $7 \%$ in milled rice and $8 \%$ in brown rice [13]. Grain quality is the most important factor in rice production as it is directly related to market value, and thus, influences farmer incomes. However, to date, little is known about the changes in grain quality over time and how fertilizer application can influence grain quality. Some evidence indicates deterioration in grain quality in modern high yielding cultivars [17]. With the current trend of regular and high consumption rate of rice in the diet, there is a need to overlook the variability in nutrient concentations within different rice varieties.

From our basic knowledge, although few studies have recently focused on interactions between Nerica and mycorrhizal inoculation [18] [19], none has yet compared this biofertilizer to chemical input, as far as nutritional quality and elemental mineral content of rice grains are concerned. Therefore, this study was investigated to assess the variations in nutritional and mineral compositions of Nerica grains harvested form field applied mycorrhiza and chemical fertilizer. It is expected that mycorrhiza-rice symbiosis would not only increase Nerica rice yield through stimulated nutrients uptake, but also would improve rice grains nutritional quality.

\section{Material and Methods}

\subsection{Experimental Location}

Field experiments were located at in Yagoua within the SEMRY plantation along the Logone river in agro-ecological zone I, and Wakwa-Ngaoundere in agroecological zone II, as previously described [20].

\subsection{Biological and Chemical Materials}

Mycorrhizal fertilizer was produced at the University of Ngaoundere, and was a mixture of soil, root fragments and spores of the genus Glomus and Gigaspora (10 à 25 spores/ $1 \mathrm{~g}$ of soil). The chemical fertilizers-NPK (fertilizer $\left.{ }^{\circledast}\right)$, with the formula 14:24:14 was purchased from a chemical fertilizer shop in Ngaoundere 
and Yagoua, the two main towns of the respective study sites. Nerica grains were provided by the Africa Rice Centre, and were a composite of five Nerica varieties namely: FKR56-N; FKR58-N; FKR60-N; FKR62-N and DIR-95. The main characteristics of rice seeds were previously described [20].

\subsection{Experimental Design and Treatments}

The experiment was carried out in a split-splot $(4 \times 5) \times 3$ design, where seeds were harvested from fertilized plants or not (treatments), while the five Nerica varieties were the sub-treatments. The main treatments were seeds from: mycorrhiza applied plants (TM); chemical fertilizer applied plants (TE); mycorrhiza-chemical fertilizer applied plants (TEM); and the control (T0). Each treatment was replicated three times.

\subsection{Assessment of Elemental Nutrients}

Elemental seed nutrients such as $\mathrm{N}, \mathrm{P}, \mathrm{Fe}, \mathrm{Mg}$ were determined after solubilization of ashes by concentrated Hydrochloric Acid [21]. Iron and phosphorus contents were evaluated through the colorimetric method described by Rodier [22]. Magnesium contents were titrimetrically assessed using the EDTA method [23].

\section{Assessment of Nutritional Components}

\subsection{Isolation of Starch}

Starch was prepared using the alkaline deproteination method [24], with some modification. Averagely $1.5 \mathrm{~g}$ of rice flour was suspended in $6 \mathrm{ml}$ of $0.05 \mathrm{~N} \mathrm{NaOH}$ at $4^{\circ} \mathrm{C}$ for $1 \mathrm{~h}$ with shaking, spun at $250 \mathrm{~g}$ (Model CR412 centrifuge, Saint-Herblain, France) for $5 \mathrm{~min}$. The supernatant and the top sticky protein layer were poured off. After three more deproteinations, flour was agitated overnight in $6 \mathrm{ml} 0.05 \mathrm{~N}$ $\mathrm{NaOH}$ at $4^{\circ} \mathrm{C}$. Starch was suspended in deionized water, neutralized with $\mathrm{HCl}$, washed three more times with deionized water, rinsed with methanol, and lyophilized. Starch lipid was removed with $85 \%$ (v/v) methanol using a Soxhlet apparatus for $16 \mathrm{~h}$.

\subsection{Determination Amylose (AC) and Amylopectin (AP) Contents}

Initially $40 \mathrm{mg}$ of pure potato amylose was weighed into a beaker. Then $1 \mathrm{ml}$ of $95 \%$ ethanol and $9 \mathrm{ml}$ of $1 \mathrm{~N} \mathrm{NaOH}$ was added and the mixture was heated in a boiling water bath for 15 minutes. The solution was allowed to cool to room temperature before transferring into a $100 \mathrm{ml}$ volumetric flask. The solution was topped up with distilled water. Aliquots of $1 \mathrm{ml}, 2 \mathrm{ml}, 3 \mathrm{ml}, 4 \mathrm{ml}$ and $5 \mathrm{ml}$ of the aforementioned solution were transferred to $100 \mathrm{ml}$ volumetric flasks covered with aluminium foils. Then series of standard solutions were prepared by adding $0.2 \mathrm{ml}, 0.4 \mathrm{ml}, 0.6 \mathrm{ml}, 0.8 \mathrm{ml}$ and $1 \mathrm{ml}$ of $1 \mathrm{~N}$ Acetic acid solution respectively. Then, $2 \mathrm{ml}$ of $0.2 \%$ Iodine solution was added to each of the flasks and shaken. All the prepared solutions were kept in a dark box for 20 minutes before absorbance 
measurement using UV-light spectrophotometer. Standard curve was drawn against the absorbance and amylose concentration. The blank solution was prepared by adding $5 \mathrm{ml}$ of $0.09 \mathrm{~N} \mathrm{NaOH}$ to $100 \mathrm{ml}$ volumetric flask, and $1 \mathrm{ml}$ of 1 $\mathrm{N}$ acetic acid-Iodine solution and kept in dark for $20 \mathrm{~min}$. before measurement of absorbance at $620 \mathrm{~nm}$. The same procedure was carried out for samples using $100 \mathrm{mg}$ of rice flour instead of standard amylose. But $5 \mathrm{ml}$ of starch solution was reacted with $1 \mathrm{ml}$ of $1 \mathrm{~N}$ acetic and $2 \mathrm{ml}$ of $0.2 \%$ iodine instead of preparing a series of solutions. Absorbance was also measured at $620 \mathrm{~nm}$. The amylose content of sample was determined as described by Juliano [25], Perez and Juliano [26].

Amylopectin content was calculated using the following equation, that uses the average amylose content value in the calculation [27].

Amylopectin (\%) $=1-$ Amylose $\%$

\subsection{Evaluation of Protein Content}

Protein content was determined as described by Wireko-Manu and Amamoo [28], following the standard method [29]. Hence, each air dried sample (2 g) was weighed into $500 \mathrm{ml}$ long-necked kjeldahl flask and moistened with $10 \mathrm{ml}$ distilled water. A full spatula of kjeldahl catalyst (mixture of 1 part selenium +10 parts $\mathrm{CUSO}_{4}+100$ parts $\mathrm{Na}_{2} \mathrm{SO}_{4}$ ) was added followed by $20 \mathrm{ml}$ concentrated $\mathrm{H}_{2} \mathrm{SO}_{4}$. The solution was digested until colourless fluid that was cooled down and decanted and made up to the mark with distilled water into a $100 \mathrm{ml}$ volumetric flask. An aliquot of $10 \mathrm{ml}$ of digested sample was transferred into $100 \mathrm{ml}$ kjeldahl distillation flask and made up to the mark with distilled water. Twenty (20) $\mathrm{ml}$ of $40 \%$ sodium hydroxide was added to the content of the distillation flask. Distillate was collected over $10 \mathrm{ml}$ of $4 \%$ boric acid and 3 drops of methyl red in a $200 \mathrm{ml}$ conical flask. The presence of nitrogen gave a light blue colour. The collected distillate (about $100 \mathrm{ml}$ ) was titrated with $0.1 \mathrm{~N} \mathrm{HCL}$ till the blue colour changed to grey and then suddenly flashed to pink. A blank determination was carried out without a sample. Crude protein was estimated by multiplying the value obtained for percentage nitrogen content by a factor of 6.25 .

\section{Statistical Analysis}

Data collected were subjected to Analysis of variance (ANOVA) mixed model at 5\% probability level using a Statgraphic Plus computer package version 5.0. Means were separated between treatments using the Least Significant Difference (LSD). All graphical illustrations were configured using Excel spread sheet. Correlations between parameters were assessed using the SPSS computer package.

\section{Results and Discussions}

\subsection{Rice Seed Mineral Contents}

$\mathrm{Cu}, \mathrm{Fe}, \mathrm{Mn}, \mathrm{Zn}, \mathrm{Na}, \mathrm{Ca}, \mathrm{K}, \mathrm{Mg}, \mathrm{S}, \mathrm{P}$, and $\mathrm{B}$ are important essential micronutrients in the human diet. Deficiency of these microelements can result to serious diseases [30]. The rate of fertilizer application and the native fertility of 
paddy fields have been reported to affect the mineral element levels of rice [31]. There was variation in mineral composition among rice varieties samples in both agro-ecological zones 1 (Yagoua) and 2 (Wakwa).

\subsection{Phosphorus (P)}

Phosphorus, the second most widely limiting nutrient in soil after nitrogen [32], is a critical macronutrient for plant growth. In tropical agro-ecosystems soil, $\mathrm{P}$ deficiency is a major limitation to crop production [33]. In this study, inoculation of rice plantlets with mycorrhiza at sowing and subsequent application of chemical fertilizer-NPK resulted in accumulation of phosphorus in harvested seeds (Figure 1).

$\mathrm{P}$ content in rice ranked from $87.26 \mathrm{mg} / 100 \mathrm{~g}$ in the control T0 (variety FKR58-N) to $232.72 \mathrm{mg} / 100 \mathrm{~g}$ seed flower in treatment TEM (variety FKR62-N) at Wakwa, and from $85.50 \mathrm{mg} / 100 \mathrm{~g}$ in the control T0 (variety FKR58-N) to $254.57 \mathrm{mg} / 100 \mathrm{~g}$ seed flower in treatment TEM (variety FKR62-N) at Yagoua. These responses were significantly more pronounced in seeds from chemical applied or mycorrhizal inoculated plants than in seeds from control plants for all the sowing varieties investigated. The results varied from one cropping season to another within experimental site, and from one experimental site to another. However, for a cropping season within experimental site, the seed phosphorus concentration differed from one seed variety to another, with seeds from rice variety FKR62-N and FKR56-N significantly accumulating more $\mathrm{P}$ than other rice varieties after inoculation. As far as treatments are concerned, seeds harvested from TEM and TE treated plants accumulated more P than those from TM and control plants. These elevated concentrations are attributed to mycorrhiza, chemical fertilizer-NPK (14-24-14), or their synergistic effects. Mycorrhiza has been reported to improve nutrient uptake in inoculated plants through increment of the exploration area around the plant rhizosphere, where the host plant can uptake nutrients [4] [5]. These nutrients are assimilated by the host plant and are found in different plants parts such as leaves, roots or seeds [34]. Rice P seed content obtained fall within the range of $106.07-259.66 \mathrm{mg} / 100 \mathrm{~g}$ repoorted by Odenigbo et al. [35] in rice varieties from Nigeria and Cameroon, and between $100.32-198.97 \mathrm{mg} / 100 \mathrm{~g}$ in milled rice samples from Ghana [36]. However, P content values were higher than $73.0 \pm 8.04 \mathrm{mg} / 100 \mathrm{~g}$ reported in a Nigerian milled rice [37].

\subsection{Iron (Fe)}

The iron concentration varied from one rice variety to another, as well as from one treatment to another (Figure 2). The Fe content in rice was comprised between $1.16-3.94 \mathrm{mg} / 100 \mathrm{~g}$ seed flour, respectively in the control (variety FKR56-N) and TEM treatment (FKR62-N) at Wakwa. At Yagoua, the corresponding 


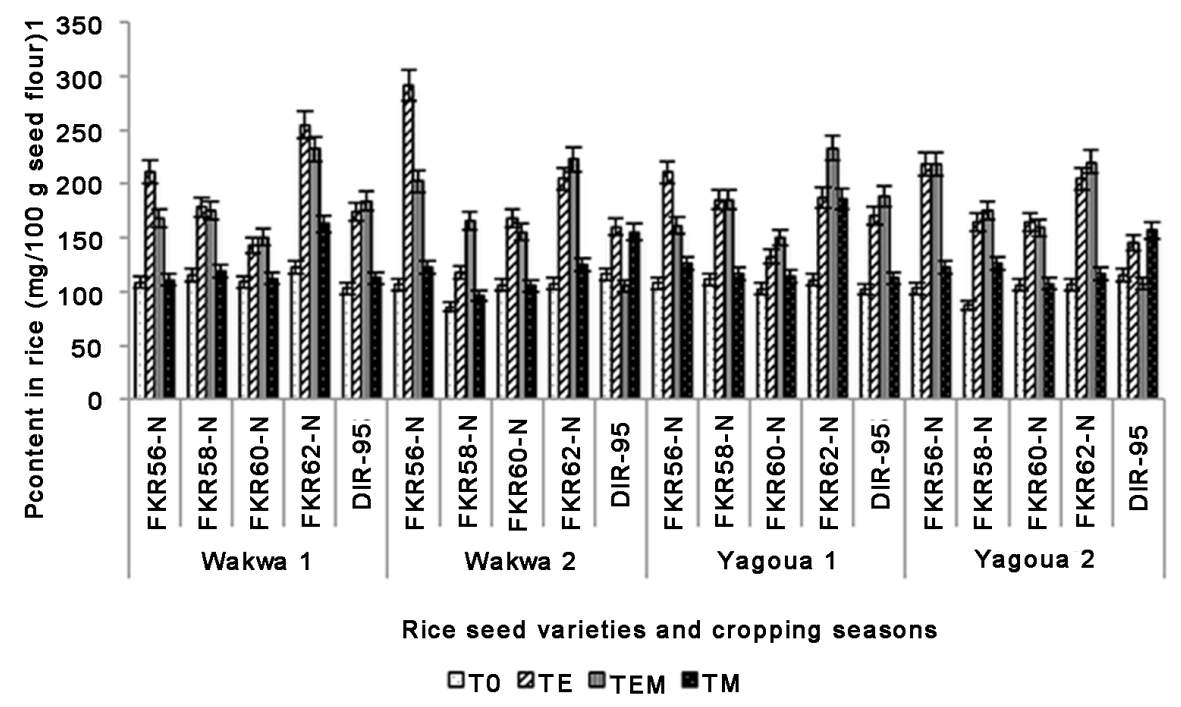

Figure 1. Changes in rice seed phosphorus contents as affected by treatments at Yagoua and Wakwa.

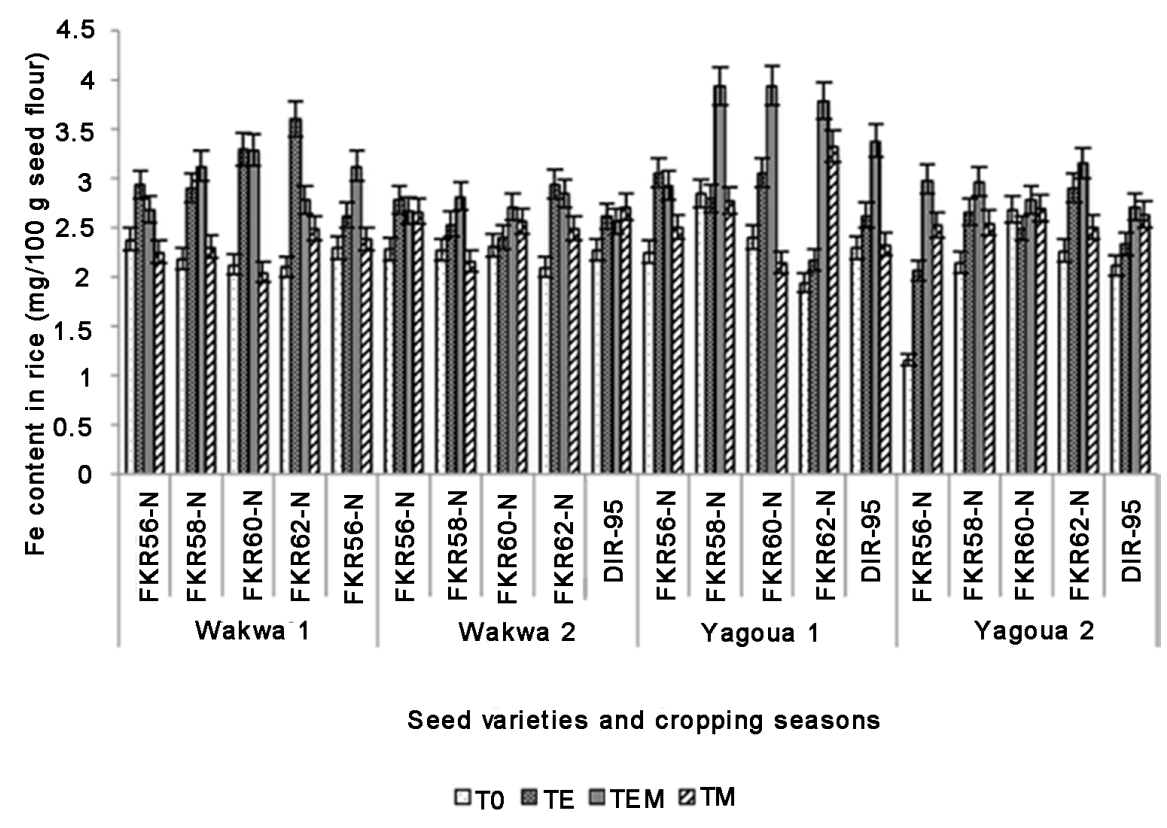

Figure 2. Changes in rice seed iron contents as affected by treatments at Yagoua and Wakwa.

values were $2.09-3.60 \mathrm{mg} / 100 \mathrm{~g}$ seed flour, respectively in the control and TEM treatment of the rice variety FKR62-N). Rice varieties FKR58-N, FKR60-N and FKR62-N had the highest iron concentration in their seeds. Iron concentration in seeds was increased by treatments TE, TEM and TM as compared to that of the control T0 at both Wakwa and Yagoua experimental sites. When plants were applied with the chemical fertilizer-NPK (treatment TE), the seed Fe concentration did not differ significantly from one rice variety to another, either at Wakwa or Yagoua during each of the cropping season. Fe rice content of $46.3 \pm 2.11 \mathrm{mg}$ / $100 \mathrm{~g}$ was detected in a Nigerian milled rice [37], which is more than 10 folds 
higher than values obtained from this study. The relative low Fe content in $\mathrm{Ne}-$ rica suggests that these varieties may be resistant to Fe accumulation in seeds.

\subsection{Nitrogen $(\mathrm{N})$}

The most important nutrient involved in mycorrhizal symbiosis was reported as $\mathrm{P}$, but seems to involve also other nutrients. P nutrition of soils is critical for the efficient use of inorganic $\mathrm{N}$ fertilizer. While $\mathrm{N}$ is the most limiting nutrient generally in soil, it has been shown that deficiency of soil $\mathrm{P}$ reduces the efficiency of $\mathrm{N}$ use by crops [38]. Our investigations reveal the contribution of treatments TE, TEM, TM to a significant improvement of $\mathrm{N}$ accumulation in rice (Figure 3). This was observed during cropping seasons 1 and 2 and in each of the experimental site. Apart from the rice variety FKR56- $\mathrm{N}$ for which treatment TE improved $\mathrm{N}$ accumulation in seed $(3.66 \mathrm{mg} / \mathrm{g}$ seed at Wakwa $1,3.99 \mathrm{mg} / 100 \mathrm{~g}$ seed at Yagoua 1), treatments TEM and TM significantly improved the $\mathrm{N}$ seed content in all the studied varieties than other treatments. The highest seed $\mathrm{N}$ contents were 4.02 and $4.06 \mathrm{mg} / 100 \mathrm{~g}$ seed flour, respectively at Wakwa 2 and Yagoua 2 for the seed variety FKR56-N applied with both chemical fertilizer-NPK and mycorrhiza (treatment TEM). The seed $\mathrm{N}$ content in treatment control (T0) was always significantly lower than that of other treatments in both experimental sites (Wakwa, Yagoua).

An increase in grain nitrogen content following increased in nitrogen fertilizer application at particular levels was recently reported by Yoseftabar et al. [39]. The maximum nitrogen contents in rice grain $(2.50 \mathrm{mg} / 100 \mathrm{~g})$ was obtained at 100 and $125 \mathrm{~kg} \mathrm{~N} \mathrm{ha}^{-1}$ [40]. In this study, we used mycorrhiza, which does not only improve P uptake, but other ntrients including nitrogen [5]. Similarly, other studies also reported enhanced $\mathrm{Fe}, \mathrm{Mn}, \mathrm{Cu}$, and $\mathrm{Zn}$ accumulation in rice and wheat grains, as the result of $\mathrm{N}$ application [41].

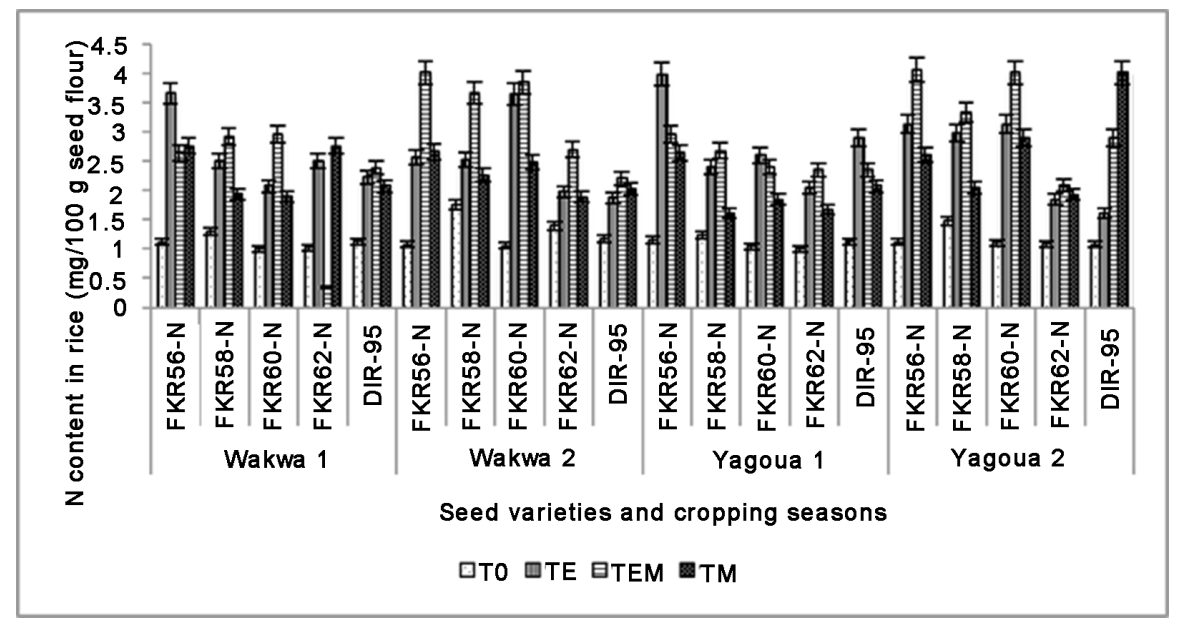

Figure 3. Changes in rice seed nitrogen contents as affected by treatments at Yagoua and Wakwa. 


\subsection{Magnesium (Mg)}

$\mathrm{Mg}$ seed content differred from one rice variety to another, and withing the rice variety from one treatment to another at both Wakwa and Yagoua experimental fields (Figure 4). The highest Mg seed content at Wakwa was obtained in the rice variety FKR $58-\mathrm{N}(188.94 \mathrm{mg} / 100 \mathrm{~g}$ seed flour at Wakwa $1,128.00 \mathrm{mg} / 100 \mathrm{~g}$ seed flour at Wakwa 2), when plants were submitted to treatment TEM. In all the studied varieties, the Mg seed content was always significantly lower in the control treatment (T0) than in other treatments, the lowest content (103.15 $\mathrm{mg} / 100 \mathrm{~g}$ seed flour) accounting for the rice variety (FKR58-N). At Yagoua, treatment TEM also improved the Mg seed content more than in other treatments, and in all the studied varieties, with the highest content observed in rice variety FKR58- N (181.79 mg/100 g seed flour) at Yagoua 1. During the second cropping season at Yagoua (Yagoua 2), Mg seed content was instead improved by treatment TM (mycorrhiza alone) in all the rice varieties, except for variety FKR58-N, for which treatment chemical fertilizer-NPK (TE) was the most efficient. However, compared to results obtained at Wakwa, Mg seed content did not significantly differ between treatments applied on varieties FKR56-N, FKR60-N and DIR-95.

The Mg seed content at Wakwa was not higher than $188 \mathrm{mg} / 100 \mathrm{~g}$ or $181 \mathrm{mg} /$ $100 \mathrm{~g}$ seed flour at Yagoua. These values fall within the range of between 112.41 $324.83 \mathrm{mg} / 100 \mathrm{~g}$ reported by Odenigbo et al. [35], which is higher than $67.0 \pm$ $7.12 \mathrm{mg} / 100 \mathrm{~g}$ revealed in a Nigerian milled rice [37].

\subsection{Rice Nutritional Seed Quality}

Based on their nutritional quality attributes, consumers and farmers should be better informed on the choice of rice varieties, although the nutritional values of

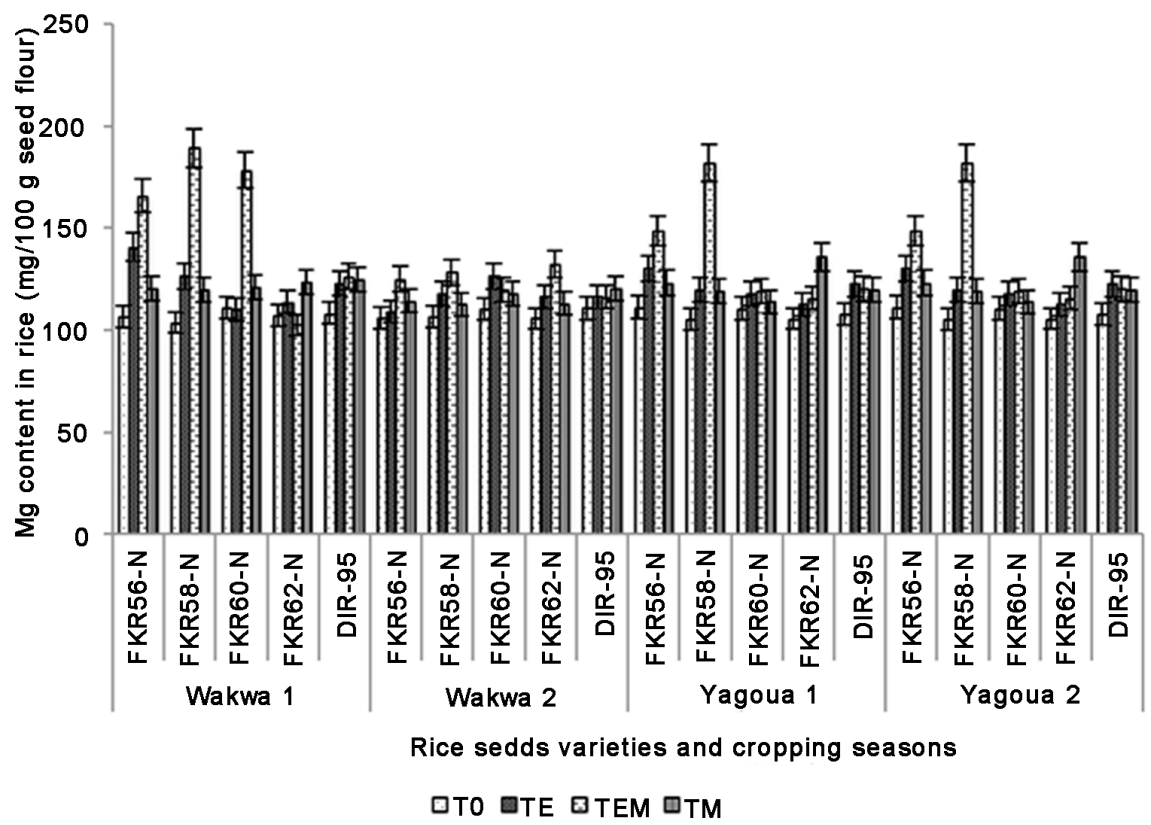

Figure 4. Changes in rice seed magnesium contents as affected by treatments at Yagoua and Wakwa. 
rice vary with different varieties, soil fertility, fertilizer application and other environmental conditions.

\subsection{Starch}

Starch is the major dietary source of carbohydrates and is the most abundant storage polysaccharide in plants. Total starch in seed ranged from $68.25 \%$ in the control of variety FKR62-N, to $76.36 \%$ and $76.5 \%$, respectively in treatment TEM for variety FKR58-N at Wakwa 1, and variety FKR62-N at Wakwa 2 (Table 1). During the first and second cropping seasons at Wakwa or Yagoua, the application of rice plants with mycorrhiza (TM) or chemical fertilizer-NPK (TE) significantly improved the starch content in seed $(\mathrm{p}<0.02)$, although this was not true for the local variety DIR-95 at Wakwa $1(\mathrm{p}=0.45)$. At Yagoua, the lowest starch content in seed was found in treatment T0 of the rice variety FKR60-N (63.84\%), whereas the highest accounted for treatment TEM of the rice variety FKR62-N (77.38\%) at Yagoua 1 (Table 2). Starch values obtained in the present study were lower than those in the range $81.23 \%-92.73 \%$ reported by Omar et al. [42], although still greater than starch content of between $68.73 \%-70.24 \%$ from different rice cultivars [43]. These variations were attributed to varietal difference [44].

\subsection{Amylopectin}

Amylopectin content in rice was determined from that of amylose [27]. Thus, the higher the amylose content, the lower that of amylopectin. For a given treatment, the seed amylopectin content significantly differed from one rice variety to another, and within a variety from one treatment to another. Treatment TEM best increased the amylopectin seed content more than other treatments. The seed amylopectin content of the control was the lowest of all the treatments either at Wakwa (Table 1), or Yagoua (Table 2) experimental sites. In both sites, the seed amylopectin content ranged between $43.64 \%$ and $54.18 \%$, corresponding to amylose content from between $45.82 \%$ and $56.36 \%$. Rice has been classified into several groups based on its amylose content, and was categorized as waxy (1\% $2 \%)$, very low amylose $(2 \%-12 \%)$, low amylose $(12 \%-20 \%)$, intermediate amylose (20\% - 24\%), and high amylose (>24\%) contents [45] [46]. According to this classification, all the rice varieties used in the present study fall under high amylose rice, and therefore, their textures in cooked form should be less sticky and harder. Previous studies on amylose content have suggested that high amylose rice varieties yield a harder and less sticky rice upon cooking, and have stipulated that hardness is positively correlated with the amylose content of rice [47]. Similarly, the amylose content in Sri Lankans rice was revealed to be non sticky, with higher content of between 25\% - 30\% [48] [49]. Amyolse content in starch maize was reported as $74.44 \%$, corresponding to an amylopectin content of $25.60 \%$ [50], thus lower than that of starch rice obtained from this study. The considerable variation in amylose and amylopectin contents in rice was reported to be attributed to elevated temperature that significantly decreased 
Table 1. Variation in nutritional components in rice varieties as affected by treatments at Wakwa.

\begin{tabular}{|c|c|c|c|c|c|c|c|}
\hline \multirow{2}{*}{$\begin{array}{l}\text { Nutrients } \\
\text { components }\end{array}$} & \multirow{2}{*}{ Treatments } & \multicolumn{5}{|c|}{ Rice varieties } & \multirow{2}{*}{ p-value (LDS) } \\
\hline & & FKR56-N & FKR58-N & FKR60-N & FKR62-N & DIR-95 & \\
\hline \multicolumn{8}{|c|}{ Cropping season 1 (Wakwa 1) } \\
\hline \multirow{6}{*}{ Total starch (\%) } & T0 & $70.32_{\mathrm{a}}^{\mathrm{bc}}$ & $72.28_{\mathrm{ac}}^{\mathrm{bc}}$ & $68.96_{\mathrm{a}}^{\mathrm{b}}$ & $66.25_{\mathrm{a}}^{a}$ & $68.65_{\mathrm{a}}^{\mathrm{b}}$ & $0.001(2.40)$ \\
\hline & $\mathrm{TE}$ & $73.72_{\mathrm{b}}^{\mathrm{a}}$ & $77.75_{\mathrm{b}}^{\mathrm{c}}$ & $71.57_{c}^{\mathrm{a}}$ & $71.50_{\mathrm{b}}^{\mathrm{a}}$ & $72.57_{\mathrm{a}}^{\mathrm{a}}$ & $0.01(4.02)$ \\
\hline & TEM & $74.13_{\mathrm{b}}^{\mathrm{c}}$ & $76.36_{b}^{d}$ & $70.69_{\mathrm{bc}}^{\mathrm{ab}}$ & $71.61_{\mathrm{b}}^{\mathrm{b}}$ & $70.58_{a}^{a}$ & $<0.0001(1.02)$ \\
\hline & $\mathrm{TM}$ & $70.50_{\mathrm{a}}^{\mathrm{b}}$ & $72.48_{\mathrm{a}}^{\mathrm{b}}$ & $69.55_{\mathrm{ab}}^{\mathrm{ab}}$ & $66.61_{\mathrm{a}}^{\mathrm{a}}$ & $69.55_{a}^{\mathrm{ab}}$ & $0.02(3.88)$ \\
\hline & $p$-value (LDS) & $0.0002(3.22)$ & $<0.0001(1.39)$ & $0.007(1.73)$ & $<0.0001(4.88)$ & 0.46 (ns) & \\
\hline & T0 & $47.20_{\mathrm{a}}^{\mathrm{b}}$ & $49.66_{\mathrm{a}}^{\mathrm{c}}$ & $46.32_{\mathrm{a}}^{\mathrm{b}}$ & $66.61_{a}^{a}$ & $46.09_{\mathrm{a}}^{\mathrm{b}}$ & $0.001(2.44)$ \\
\hline \multirow{4}{*}{ Amylopectin (\%) } & $\mathrm{TE}$ & $50.21_{\mathrm{b}}^{\mathrm{a}}$ & $54.18_{\mathrm{b}}^{\mathrm{b}}$ & $48.60_{\mathrm{c}}^{\mathrm{a}}$ & $48.06_{b}^{a}$ & $48.73_{\mathrm{a}}^{\mathrm{a}}$ & $0.02(3.97)$ \\
\hline & TEM & $50.72_{\mathrm{b}}^{\mathrm{a}}$ & $53.26_{\mathrm{b}}^{\mathrm{c}}$ & $47.78_{\mathrm{bc}}^{\mathrm{a}}$ & $48.04_{b}^{\mathrm{a}}$ & $47.66_{a}^{\mathrm{a}}$ & $<0.0001(2.54)$ \\
\hline & $\mathrm{TM}$ & $47.83_{\mathrm{a}}^{\mathrm{bc}}$ & $49.99_{\mathrm{a}}^{\mathrm{c}}$ & $46.77_{\mathrm{ab}}^{\mathrm{abc}}$ & $44.141_{a}^{\mathrm{a}}$ & $46.44_{\mathrm{a}}^{\mathrm{ab}}$ & $0.03(3.55)$ \\
\hline & $p$-value (LDS) & $0.0009(2.37)$ & $0.0001(3.26)$ & $0.01(1.46)$ & $<0.0001(3.90)$ & $0.71(\mathrm{~ns})$ & \\
\hline \multirow{5}{*}{ Proteins (\%) } & T0 & $6.92_{\mathrm{a}}^{\mathrm{bc}}$ & $7.30_{\mathrm{a}}$ & $6.23_{\mathrm{a}}^{\mathrm{a}}$ & $5.97_{\mathrm{a}}^{\mathrm{a}}$ & $6.76_{a}^{b}$ & $0.002(0.07)$ \\
\hline & $\mathrm{TE}$ & $23.74_{d}^{d}$ & $14.29_{\mathrm{d}}^{\mathrm{b}}$ & $12.27_{c}^{\mathrm{a}}$ & $12.22_{\mathrm{c}}^{\mathrm{a}}$ & $17.26_{c}^{c}$ & $<0.0001(2.97)$ \\
\hline & TEM & $17.66_{\mathrm{c}}^{\mathrm{c}}$ & $15.96_{\mathrm{b}}^{\mathrm{c}}$ & $14.16_{\mathrm{d}}^{\mathrm{a}}$ & $14.03_{\mathrm{d}}^{\mathrm{a}}$ & $14.04_{\mathrm{bc}}^{\mathrm{a}}$ & $<0.0001(1.70)$ \\
\hline & $\mathrm{TM}$ & $15.75_{\mathrm{b}}^{\mathrm{c}}$ & $14.29_{\mathrm{b}}^{\mathrm{a}}$ & $11.02_{\mathrm{b}}^{\mathrm{ab}}$ & $10.0_{\mathrm{b}}^{\mathrm{a}}$ & $12.41_{\mathrm{b}}^{\mathrm{b}}$ & $0.0006(2.41)$ \\
\hline & $p$-value (LDS) & $<0.0001(1.91)$ & $<0.0001(1.67)$ & $<0.0001(1.25)$ & $<0.0001(1.85)$ & $0.0008(4.84)$ & \\
\hline \multicolumn{8}{|c|}{ Cropping season 2 (Wakwa 2) } \\
\hline \multirow{5}{*}{ Total starch (\%) } & T0 & $67.90_{\mathrm{a}}^{\mathrm{a}}$ & $68.94_{\mathrm{a}}^{\mathrm{a}}$ & $67.50_{\mathrm{a}}^{\mathrm{a}}$ & $68.9_{\mathrm{a}}^{\mathrm{a}}$ & $67.36_{\mathrm{a}}^{\mathrm{a}}$ & 0.19 (ns) \\
\hline & $\mathrm{TE}$ & $70.77_{\mathrm{b}}^{\mathrm{ab}}$ & $73.01_{\mathrm{b}}^{\mathrm{bc}}$ & $70.08_{b}^{a}$ & $74.70_{\mathrm{c}}^{\mathrm{c}}$ & $68.33_{\mathrm{a}}^{\mathrm{a}}$ & $0.003(2.93)$ \\
\hline & TEM & $70.17_{\mathrm{b}}^{\mathrm{b}}$ & $74.56_{\mathrm{c}}^{\mathrm{c}}$ & $69.78_{\mathrm{b}}^{\mathrm{b}}$ & $76.57_{\mathrm{d}}^{\mathrm{d}}$ & $67.49_{a}^{a}$ & $<0.0001(2.01)$ \\
\hline & $\mathrm{TM}$ & $66.62_{\mathrm{a}}^{\mathrm{a}}$ & $69.51_{\mathrm{a}}^{\mathrm{b}}$ & $67.49_{\mathrm{a}}^{\mathrm{a}}$ & $70.87_{b}^{c}$ & $69.78_{a}^{b c}$ & $0.0002(1.36)$ \\
\hline & $p$-value (LDS) & $0.0006(2.27)$ & $<0.0001(1.54)$ & $0.002(2.28)$ & $<0.0001(1.97)$ & $0.40(\mathrm{~ns})$ & \\
\hline \multirow{5}{*}{ Amylopectin (\%) } & T0 & $45.52_{b}^{a}$ & $46.00_{\mathrm{a}}^{\mathrm{ab}}$ & $44.83_{a}^{a}$ & $47.28_{\mathrm{a}}^{\mathrm{b}}$ & $44.71_{a}^{a}$ & $0.040(1.75)$ \\
\hline & $\mathrm{TE}$ & $47.78_{c}^{\mathrm{ab}}$ & $49.14_{b}^{b}$ & $46.76_{\mathrm{b}}^{\mathrm{ab}}$ & $51.71_{c}^{b}$ & $45.79_{\mathrm{a}}^{\mathrm{a}}$ & $0.002(2.57)$ \\
\hline & TEM & $47.56_{c}^{b}$ & $51.24_{c}^{c}$ & $46.48_{\mathrm{ab}}^{\mathrm{b}}$ & $53.63_{d}^{d}$ & $44.82_{\mathrm{a}}^{\mathrm{a}}$ & $<0.0001(1.66)$ \\
\hline & $\mathrm{TM}$ & $43.82_{a}^{a}$ & $46.48_{\mathrm{a}}^{\mathrm{b}}$ & $44.82_{\mathrm{a}}^{\mathrm{a}}$ & $48.88_{b}^{c}$ & $46.48_{b}^{a}$ & $<0.0001(1.66)$ \\
\hline & $p$-value (LDS) & $0.0001(1.70)$ & $<0.0001(0.05)$ & $0.04(2.10)$ & $<0.0001(1.60)$ & 0.48 (ns) & \\
\hline \multirow{5}{*}{ Proteins (\%) } & T0 & $6.66_{a}^{a}$ & $8.85_{\mathrm{a}}^{\mathrm{b}}$ & $6.61_{\mathrm{a}}^{\mathrm{a}}$ & $6.53_{\mathrm{a}}^{\mathrm{a}}$ & $6.48_{\mathrm{a}}^{\mathrm{a}}$ & $<0.0001(0.19)$ \\
\hline & $\mathrm{TE}$ & $18.61_{c}^{b}$ & $17.73_{\mathrm{c}}^{\mathrm{b}}$ & $18.61_{c}^{b}$ & $11.02_{\mathrm{b}}^{\mathrm{a}}$ & $10.59_{\mathrm{b}}^{\mathrm{a}}$ & $<0.0001(6.71)$ \\
\hline & TEM & $24.35_{d}^{d}$ & $19.81_{d}^{c}$ & $23.92_{\mathrm{d}}^{\mathrm{d}}$ & $12.47_{\mathrm{d}}^{\mathrm{a}}$ & $17.31_{c}^{b}$ & $<0.0001(2.50)$ \\
\hline & $\mathrm{TM}$ & $15.52_{\mathrm{b}}^{\mathrm{c}}$ & $12.21_{\mathrm{b}}^{\mathrm{b}}$ & $17.31_{b}^{\mathrm{d}}$ & $11.50_{c}^{\mathrm{a}}$ & $23.92_{\mathrm{d}}^{\mathrm{e}}$ & $<0.0001(0.71)$ \\
\hline & $p$-value (LDS) & $<0.0001(3.09)$ & $<0.0001(2.08)$ & $<0.0001(1.30)$ & $<0.0001(0.97)$ & $<0.0001(4.11)$ & \\
\hline
\end{tabular}

For each cropping season and for each nutritional parameter, values in a column affected by the same letter as a lower case are not significantly different at the level of probability indicated. For treatment of a particular nutritional parameter, values in a row affected by the same letter as a upper case are not significantly different at the level of probability indicated. 
Table 2. Variation in nutritional components in rice varieties as affected by treatments at Yagoua.

\begin{tabular}{|c|c|c|c|c|c|c|c|}
\hline \multirow{2}{*}{$\begin{array}{l}\text { Nutrients } \\
\text { components }\end{array}$} & \multirow{2}{*}{ Treatments } & \multicolumn{5}{|c|}{ Rice varieties } & \multirow{2}{*}{$p$-value (LDS) } \\
\hline & & FKR56-N & FKR58-N & FKR60-N & FKR62-N & DIR-95 & \\
\hline \multicolumn{8}{|c|}{ Cropping season 1 (Yagoua 1) } \\
\hline \multirow{5}{*}{ Total starch (\%) } & T0 & $69.10_{\mathrm{a}}^{\mathrm{c}}$ & $68.16_{\mathrm{a}}^{\mathrm{bc}}$ & $63.84_{\mathrm{a}}^{\mathrm{a}}$ & $68.65^{c}$ & $66.45_{\mathrm{a}}^{\mathrm{b}}$ & $0.001(2.20)$ \\
\hline & $\mathrm{TE}$ & $72.80_{\mathrm{b}}^{\mathrm{bc}}$ & $71.97_{\mathrm{b}}^{\mathrm{bc}}$ & $70.05_{c}^{\mathrm{ab}}$ & $75.02_{c}^{c}$ & $68.18_{\mathrm{a}}^{\mathrm{a}}$ & $0.005(3.79)$ \\
\hline & TEM & $73.63_{\mathrm{b}}^{\mathrm{a}}$ & $75.52_{c}^{\mathrm{a}}$ & $74.66_{\mathrm{d}}^{\mathrm{a}}$ & $77.38_{\mathrm{d}}^{\mathrm{a}}$ & $74.92_{\mathrm{b}}^{\mathrm{a}}$ & 0.43 (ns) \\
\hline & $\mathrm{TM}$ & $69.07_{\mathrm{a}}^{\mathrm{ab}}$ & $70.13_{\mathrm{ab}}^{\mathrm{bc}}$ & $66.95_{\mathrm{b}}^{\mathrm{a}}$ & $72.50_{\mathrm{b}}^{\mathrm{c}}$ & $69.72_{\mathrm{ab}}^{\mathrm{b}}$ & $0.005(2.77)$ \\
\hline & $p$-value (LDS) & $0.0002(3.70)$ & $0.001(3.54)$ & $0.0002(3.10)$ & $0.0001(2.36)$ & $0.02(6.73)$ & \\
\hline \multirow{5}{*}{ Amylopectin (\%) } & T0 & $45.52_{\mathrm{b}}^{\mathrm{a}}$ & $46.00_{\mathrm{a}}^{\mathrm{ab}}$ & $44.84_{\mathrm{a}}^{\mathrm{a}}$ & $47.28_{\mathrm{a}}^{\mathrm{b}}$ & $44.71_{\mathrm{a}}^{\mathrm{a}}$ & $0.040(1.75)$ \\
\hline & TE & $47.78_{c}^{\mathrm{ab}}$ & $49.14_{b}^{\mathrm{cd}}$ & $46.76_{\mathrm{b}}^{\mathrm{a}}$ & $51.43_{c}^{d}$ & $45.79_{\mathrm{a}}^{\mathrm{a}}$ & $0.002(2.38)$ \\
\hline & TEM & $47.56_{\mathrm{c}}^{\mathrm{b}}$ & $51.24_{c}^{c}$ & $46.49_{\mathrm{ab}}^{\mathrm{b}}$ & $51.43_{\mathrm{d}}^{\mathrm{d}}$ & $44.82_{\mathrm{a}}^{\mathrm{a}}$ & $<0.0001(1.67)$ \\
\hline & $\mathrm{TM}$ & $43.82_{\mathrm{a}}^{\mathrm{a}}$ & $46.48_{\mathrm{b}}^{\mathrm{a}}$ & $44.82_{\mathrm{a}}^{\mathrm{a}}$ & $48.88_{b}^{c}$ & $46.48_{\mathrm{a}}^{\mathrm{b}}$ & $<0.0001(1.66)$ \\
\hline & $p$-value (LDS) & $0.0001(1.70)$ & $<0.0001(2.10)$ & $0.04(1.92)$ & $<0.0001(1.60)$ & $0.48(\mathrm{~ns})$ & \\
\hline \multirow{5}{*}{ Proteins (\%) } & T0 & $6.66_{\mathrm{a}}^{\mathrm{a}}$ & $8.85_{\mathrm{a}}^{\mathrm{b}}$ & $6.61_{\mathrm{a}}^{\mathrm{a}}$ & $6.53_{a}^{a}$ & $6.48_{\mathrm{a}}^{\mathrm{a}}$ & $<0.0001(2.19)$ \\
\hline & $\mathrm{TE}$ & $18.64_{c}^{\mathrm{b}}$ & $17.73_{\mathrm{c}}^{\mathrm{b}}$ & $18.61_{\mathrm{c}}^{\mathrm{b}}$ & $11.02_{\mathrm{b}}^{\mathrm{a}}$ & $10.59_{\mathrm{b}}^{\mathrm{a}}$ & $<0.0001(6.71)$ \\
\hline & TEM & $24.35_{d}^{d}$ & $19.81_{d}^{c}$ & $23.92_{d}^{d}$ & $12.47_{d}^{a}$ & $17.31_{c}^{b}$ & $<0.0001(2.50)$ \\
\hline & $\mathrm{TM}$ & $15.52_{\mathrm{b}}^{\mathrm{c}}$ & $12.21_{\mathrm{b}}^{\mathrm{b}}$ & $17.31_{\mathrm{b}}^{\mathrm{d}}$ & $11.53_{\mathrm{c}}^{\mathrm{e}}$ & $23.92_{\mathrm{d}}^{\mathrm{a}}$ & $<0.0001(0.67)$ \\
\hline & $p$-value (LDS) & $<0.0001(3.11)$ & $<0,0001(2.08)$ & $<0.0001(1.30)$ & $<0.0001(0.51)$ & $<0.0001(4.11)$ & \\
\hline \multicolumn{8}{|c|}{ Cropping season 2 (Yagoua 2) } \\
\hline \multirow{5}{*}{ Total starch (\%) } & T0 & $64.61_{a}^{a}$ & $72.30_{\mathrm{a}}^{\mathrm{c}}$ & $68.87_{\mathrm{a}}^{\mathrm{bc}}$ & $66.23_{\mathrm{a}}^{\mathrm{ab}}$ & $67.26_{\mathrm{a}}^{\mathrm{ab}}$ & $0.01(4.26)$ \\
\hline & $\mathrm{TE}$ & $73.84_{c}^{\mathrm{a}}$ & $77.75_{\mathrm{b}}^{\mathrm{b}}$ & $71.57_{c}^{\mathrm{a}}$ & $72.74_{c}^{\mathrm{a}}$ & $73.92_{c}^{\mathrm{a}}$ & $0.01(2.83)$ \\
\hline & TEM & $74.48_{c}^{\text {bc }}$ & $76.36_{b}^{d}$ & $70.69_{c}^{a}$ & $73.04_{c}^{b}$ & $74.73_{\mathrm{c}}^{\mathrm{c}}$ & $0.0001(1.62)$ \\
\hline & $\mathrm{TM}$ & $71.20_{\mathrm{ab}}^{\mathrm{a}}$ & $72.74_{\mathrm{a}}^{\mathrm{a}}$ & $69.68_{\mathrm{ab}}^{\mathrm{a}}$ & $69.81_{b}^{a}$ & $70.78_{\mathrm{ab}}^{\mathrm{a}}$ & 0.14 (ns) \\
\hline & $p$-value (LDS) & $0.004(6.59)$ & $0.001(3.62)$ & $0.008(1.82)$ & $0.0003(2.93)$ & $0.01(6.65)$ & \\
\hline \multirow{5}{*}{ Amylopectin (\%) } & T0 & $48.05_{a}^{b c}$ & $49.66_{\mathrm{a}}^{\mathrm{c}}$ & $46.32_{\mathrm{a}}^{\mathrm{ab}}$ & $43.64_{a}^{a}$ & $46.09_{\mathrm{a}}^{\mathrm{ab}}$ & $0.0008(3.33)$ \\
\hline & $\mathrm{TE}$ & $50.21_{\mathrm{b}}^{\mathrm{ab}}$ & $54.18_{\mathrm{b}}^{\mathrm{b}}$ & $48.60_{\mathrm{b}}^{\mathrm{ab}}$ & $48.06_{b}^{a}$ & $48.73_{\mathrm{a}}^{\mathrm{ab}}$ & $0.020(6.12)$ \\
\hline & TEM & $50.72_{\mathrm{b}}^{\mathrm{b}}$ & $53.26_{\mathrm{b}}^{\mathrm{c}}$ & $47.78_{\mathrm{ab}}^{\mathrm{a}}$ & $48.04_{b}^{a}$ & $47.68_{\mathrm{a}}^{\mathrm{a}}$ & $<0.0001(2.54)$ \\
\hline & $\mathrm{TM}$ & $47.83_{\mathrm{a}}^{\mathrm{ab}}$ & $49.99_{\mathrm{a}}^{\mathrm{b}}$ & $46.77_{\mathrm{ab}}^{\mathrm{ab}}$ & $44.14_{\mathrm{a}}^{\mathrm{a}}$ & $46.44_{\mathrm{a}}^{\mathrm{ab}}$ & $0.03(5.85)$ \\
\hline & $p$-value (LDS) & $0.0008(2.15)$ & $0.0001(3.26)$ & $0.019(2.27)$ & $<0.0001(4.40)$ & $0.71(\mathrm{~ns})$ & \\
\hline \multirow{5}{*}{ Proteins (\%) } & T0 & $6.92_{\mathrm{a}}^{\mathrm{bc}}$ & $7.30_{\mathrm{a}}^{\mathrm{c}}$ & $6.23_{\mathrm{a}}^{\mathrm{a}}$ & $5.97_{a}^{a}$ & $6.76_{\mathrm{a}}^{\mathrm{b}}$ & $0.0002(0.53)$ \\
\hline & $\mathrm{TE}$ & $23.74_{d}^{c}$ & $14.29_{\mathrm{c}}^{\mathrm{a}}$ & $12.27_{\mathrm{c}}^{\mathrm{a}}$ & $12.22_{\mathrm{c}}^{\mathrm{a}}$ & $17.26_{\mathrm{c}}^{\mathrm{b}}$ & $<0.0001(2.97)$ \\
\hline & TEM & $17.66_{\mathrm{c}}^{\mathrm{c}}$ & $15.96_{\mathrm{d}}^{\mathrm{b}}$ & $14.16_{d}^{a}$ & $14.03_{d}^{a}$ & $14.03_{\mathrm{bc}}^{\mathrm{a}}$ & $<0.0001(1.70)$ \\
\hline & $\mathrm{TM}$ & $15.75_{b}^{c}$ & $9.88_{b}^{a}$ & $11.02_{\mathrm{b}}^{\mathrm{ab}}$ & $10.00_{\mathrm{b}}^{\mathrm{a}}$ & $12.41_{\mathrm{b}}^{\mathrm{b}}$ & $0.0007(2.41)$ \\
\hline & $p$-value (LDS) & $<0.0001(1.91)$ & $<0.0001(1.67)$ & $<0.0001(1.25)$ & $<0.0001(1.80)$ & $0.0008(4.84)$ & \\
\hline
\end{tabular}

For each cropping season and for each nutritional parameter, values in a column affected by the same letter as a lower case are not significantly different at the level of probability indicated. For treatment of a particular nutritional parameter, values in a row affected by the same letter as a upper case are not significantly different at the level of probability indicated. 
the amylose content, thus increasing the amylopectin content [47] [51]. Surprisingly, although temperature at Yagoua experimental site $\left(27^{\circ} \mathrm{C}-34^{\circ} \mathrm{C}\right)$ was higher than that of Wakwa $\left(18^{\circ} \mathrm{C}-25^{\circ} \mathrm{C}\right)$, it did not affect the amylose and amylopectin contents in studied rice varieties. The more amylose there is, the slower is the digestion of rice, and the lower is the glycemic index [52]. This finding suggests that all our studied varieties which fall within higher amylose content category may positively have effect on blood sugar.

\subsection{Proteins}

Protein content in seeds was significantly lower in the control than in any other treatment applied on plants at Wakwa or Yagoua experimental sites. The highest seed protein content was obtained when plants were applied with chemical fertilizer-NPK, mycorrhiza or both, treatment TEM being the best. The rice variety FKR56-N was found to accumulate averagely more seed protein $(24.35 \%)$ at Wakwa 1/Yagoua 1, against $17.66 \%$ at Wakwa 2/Yagoua 2 (Table 1 and Table 2). This was higher than the range obtained by Edeogu et al. [53], who analyzed the proximate composition of rice in Ebonyi Sate. According to the same authors, this was attributed to prolonged parboiling which lowers the protein content of rice and some other environmental and edaphic factors. Chemical fertilizers provide plant with nutrients, particularly $\mathrm{N}, \mathrm{P}, \mathrm{K}$, while mycorrhiza improve nutrient uptake of these nutrients. Since $\mathrm{N}$ and $\mathrm{P}$ are involved in protein synthesis, it is obvious to find plant applied with chemical fertilizers or mycorrhiza expressing more proteins than control plants. After carbohydrate, protein is the second most abundant constituent of rice [54]. Rice protein is of very high quality as compared to other food crops. Some of the rice varieties had varying levels of protein which could be said to be 2.5 folds high when compared to the reported values of Eggum et al. [55]. This might be as a result of genotype and environmental differences. Besides genotypic variation, edaphic factors were suggested to lower the protein content of rice [2]. This variation was also reported to be due to genetic factors or the mineral content of the soil [56]. Varietal difference in protein was attributed to several factors including environmental stresses such as salinity and alkalinity, temperatures, diseases, total nitrogen in the soil and other minerals such as molybdenum and total chlorine which tend to increase the grain protein content [44]. The results obtained from this study are very high compared to those of earlier studies reported by Pederson and Eggum [57]. Since all samples in the present study were submitted to the same degree of milling, the observation of varied proximate composition is attributed to varietal differences and different planting locations. Numerous factors influencing nutritive value of crops at different locations have been reported to include soil type, fertilizer application, climate, harvest time, handling and storage of crop before analysis [58] [59].

\section{Conclusion}

At the end of this study varied levels of nutritional and mineral composition 
among a local rice and Nerica varieties were evidenced. The local DIR-95 variety had values close to those of Nerica varieties in all the parameters assessed. Protein contents in investigated varieties were high and ranged from 17.66\% $24.35 \%$. The local rice (DIR-95) and Nerica varieties of the present study failed within high amylose rice. Seeds from mycorrhiza and chemical fertilizer applied plants had mineral and nutritional values superior to those of seeds from other treatments. The results of this study could be exploited by rice consumers in their choice regarding the mineral and nutritional compositions, with more attention on Nerica FKR62-N variety. Hence, it could be recommended along with local DIR-95 variety under mycorrhiza inoculation in the field.

\section{Acknowledgements}

The authors are grateful to Institute for Agricultural Research and Development (IRAD, Yaounde) and the AfricaRice for their financial support.

\section{References}

[1] Hossain, M. and Fischer, K.S. (1995) Rice Research for Food Security and Sustainable Development in Asia: Achievements and Future Challenges. GeoJeornal, 35, 286-298. https://doi.org/10.1007/BF00989136

[2] Oko, A.O., Ubi, B.E., Efisue, A.A. and Dambaba, N. (2012) Comparative Analysis of the Chemical Nutrient Composition of Selected Local and Newly Introduced Rice Varieties Grown in Ebonyi State of Nigeria. International Journal of Agriculture and Forestry, 2, 16-23. https://doi.org/10.5923/j.ijaf.20120202.04

[3] Matsunami, M., Matsunami, T. and Kokubun, M. (2009) Growth and Yield of New Rice for Africa (NERICAs) under Different Ecosystems and Nitrogen Levels. Plant Production Science, 12, 381-389. https://doi.org/10.1626/pps.12.381

[4] Smith, S.E. and Read D.J. (1997) Mineral Nutrition, Heavy Metal Accumulation and Water Relation of VA Mycorrhizal Plants, 127-160. In: Mycorrhizal Symbiosis, Academic Press, London, New York, 605 p.

[5] Ngakou, A., Nwaga, D., Nebane, C.L.N., Ntonifor, N.N., Tamò, M. and Parh, I.A. (2007) Arbuscular-Mycorrhizal Fungi, Rhizobia and Metarhizium Anisopliae Enhance $\mathrm{P}, \mathrm{N}, \mathrm{Mg}, \mathrm{K}$, and Ca Accumulations in Fields Grown Cowpea. Journal of Plant Sciences, 2, 518-529. https://doi.org/10.3923/jps.2007.518.529

[6] Auge, R.M. (2001) Water Relations, Drought and Vesicular Arbuscular Mycorrhizal Symbiosis. Mycorrhiza, 11, 3-42. https://doi.org/10.1007/s005720100097

[7] Sharma, N., Yadav, K., Cheema, J., Badda, N. and Aggarwal, A. (2015) Arbuscular Mycorrhizal Symbiosis and Water Stress: A Critical Review. Tropical Agricultural Science, 38, 427-453.

[8] Savci, S. (2012) An Agricultural Pollutant: Chemical Fertilizer. International Journal of Environmental Science and Development, 3, 77-80. https://doi.org/10.7763/IJESD.2012.V3.191

[9] Ngakou, A. (2007) Potential of Selected Biofertilizers and a Mycopesticide in Managing Megalurothrips sjostedti and Improving Cowpea Production in Cameroon. Department of Biochemistry and Microbiology, University of Buea, Cameroon, 197 p.

[10] Ngakou, A., Mbaiguinam, M., Nadjilom, Y. and Tokam, N.M. (2013) Agro- Mor- 
phological and Physical Paddy Seed Attributes of Nerica and Local Rice Varieties as Affected by Mycorrhizal Inoculation and Compost Application under Upland Conditions. International Journal of Agricultural Science and Research, 3, 43-62.

[11] Abeysundara, A., Navaratne, S., Wickramasinghe, I. and Ekanayake, D. (2015) Determination of Changes of Amylose and Amylopectin Content of Paddy during Early Storage. International Journal of Science and Research, 6, 2094-2097.

[12] Juliano, B.O. (1985) Criteria and Tests for Rice Grain Qualities. In: Rice Chemistry and Technology, 2nd Edition, American Association of Cereal Chemists, 443-524.

[13] Ahuja, U., Ahuja, S.C., Thakrar, R. and Singh, R.K. (2008) Rice. A Nutraceutical. Asian Agri-History, 12, 93-108.

[14] Juliano, B.O. and Duff, B. (1991) Rice Grain Quality as an Emerging Priority in National Breeding Programs. In: Rice Grain Marketing and Quality Issues, International Rice Research Institute, Los Banos, 5564 p.

[15] Welch, R.M. and Graham, R.D. (2002) Breeding Crops for Enhanced Micronutrient Content. Plant and Soil, 245, 205-214. https://doi.org/10.1023/A:1020668100330

[16] Donald, K. (2002) The Importance of Rice. Science, 296, 13. https://doi.org/10.1126/science.296.5565.13

[17] Zhang, Q. (2007) Strategies for Developing Green Super Rice. Proceeding of the national Academy of Science USA, 104, 16402-16409. https://doi.org/10.1073/pnas.0708013104

[18] Sakariyawo, O.S., Okeleye, KA., Dare, M.O., Oyekanmi, A.A., Aderibigbe, S.G., Ogundaini, O.G., Olubode, A.A, Soreni, P.A. and Adeyeri, O.R. (2014) Performance of Some Selected NERICA Rice Inoculated with Arbuscular Mycorrhiza Fungi (AMF) for Double Cropping in the Rainforest Transitory Zone of Nigerian. Journal of Crop Science, 2, 17-26.

[19] Oladele, S.O. and Awadun, M.A. (2014) Influence of Mycorrhizae and Rhizobium Inoculation on Growth Nutrient Uptake and Proximal Composition of Upland Rice Cultivars. Journal of Natural Science Research, 4, 42-52.

[20] Gandebe, M., Ngakou, A. and Ndjouenkeu, R. (2017) Agronomic Adaptability of Some Selected Nerica Rice Varieties in Response to Biofertilizer Application in Northern Cameroon. Journal of Experimental Agriculture International, 15, 1-12.

[21] Maynard, A.J. (1970) Methods in Food Analysis: Physical, Chemical and Instrumental Methods of Analysis. 2nd Edition, Academic Press, San Francisco, London, $845 \mathrm{p}$.

[22] Rodier, J. (1978) L'analyse de l'eau: Chimie physico-chimie, bactériologie, biologie. Dunod Technique, Paris.

[23] AFNOR (Association Française de Normalisation) (1982) Recueil des normes françaises des produits dérivés des fruits et légumes. Jus de fruits, Paris, $327 \mathrm{p}$.

[24] Patindol, J., Wang, Y.J., Siebenmorgen, T. and Jane, J.L. (2003) Properties of Flours and Starches as Affected by Rough Rice Drying Regime. Cereal Chemistry, 80, 30 34. https://doi.org/10.1094/CCHEM.2003.80.1.30

[25] Juliano, B.O. (1971) Simplified Assay for Milled-Rice Amylose. Cereal Science Today, 16, 334-338.

[26] Perez, C.M. and Juliano, B.O. (1978) Modification of the Simplified Amylose Test for Milled Rice. Starch-Stärke, 30, 424-426. https://doi.org/10.1002/star.19780301206

[27] Torruco-Uco, J.G., Chel-Guerrero, L.A. and Betancur-Ancona, D. (2006) Isolation and Molecular Characterization of Makal (Xanthosoma yucatanensis) Starch. 
Starch-Stärke, 58, 300-307. https://doi.org/10.1002/star.200500451

[28] Wireko-Manu, F.D. and Amamoo, C. (2017) Comparative Studies on Proximate and Some Mineral Composition of Selected Local Rice Varieties and Imported Rice Brands in Ghana. Agriculture and Food Sciences Research, 4, 1-7.

[29] AOAC (Association of Analytical Chemists) (1984) Standard Official Methods of Analysis of the Association of Analytical Chemists. 14th Edition, S.W Williams, Washington DC, $121 \mathrm{p}$.

[30] Gu, J., Chen, J., Chen, L., Wang, Z., Zhang, H. and Yang, J. (2015) Grain Quality Changes and Responses to Nitrogen Fertilizer of Japonica Rice Cultivars Released in the Yangtze River Basin from the 1950s to 2000s. The Crop Journal, 3, 285-297.

[31] Nwilene, F.E., Oikeh, S.O., Agunbiade, T.A., Oladimeji, O., Ajayi, O., Sie, M., Gregorio, G.B., Togota, A. and Taura, A.D. (2007) Increasing Rice Production in SubSaharan Africa, Challenges and Opportunities, A Production Hand Book, Africa.

[32] Balemi, T. and Negisho, L. (2012) Management of Soil Phosphorus and Plant Adaptation Mechanisms to Phosphorus Stress for Sustainable Crop Production: A Review. Journal of Soil Science and Plant Nutrition, 12, 547-562.

[33] Mustonen, P.J., Oelbermann, M. and Kass, D.C.L. (2012) Using Tithonia dive- rsifolia (Hemsl.) Gray, in a Short Fallow System to Increase Soil Phosphorus Availability on a Costa Rican Andosol. Journal of Agricultural Science, 4, 91-100.

[34] Bolan, N.S. (1991) A Critical Review on the Role of Mycorrhizal Fungi in the Uptake of Phosphorus by Plants. Plant and Soil, 134, 189-207.

https://doi.org/10.1007/BF00012037

[35] Odenigbo, A.M., Danbaba. N. and Ngadi, M. (2014) Nutrient Composition and Predicted Glycemic Index of Rice Varieties from Nigeria. British Journal of Applied Science and Technology, 4, 302-318. https://doi.org/10.9734/BJAST/2014/6203

[36] Adu-Kwarteng, E., Ellis, W., Oduro, I. and Manful, J. (2003) Rice Grain Quality: A Comparison of Local Varieties with New Varieties under Study in Ghana. Food Control, 14, 507-514.

[37] Ebuehi, O.A.T. and Oyewole, A.C. (2007) Effect of Cooking and Soaking on Physical Characteristics, Nutrient Composition and Sensory Evaluation of Indigenous and Foreign Rice Varieties in Nigeria. African Journal of Biotechnology, 6, 1016-1020.

[38] Delve, R.J., Probert, M.E., Cobo, J.G., Ricaurte, J., Rivera, M., Barrios, E. and Rao, I.M. (2009) Simulating Phosphorus Resepose in Annual Crop Using APSIM; Model Evaluation on Contrasting Soil Types. Nutrient Cycling in Agroecosystems, 84, 293306. https://doi.org/10.1007/s10705-008-9243-6

[39] Yoseftabar, S., Fallah, A. and Daneshian, J. (2012) Comparing of Yield and Yield Components of Hybrid Rice (GRH1) in Different Application of Nitrogen Fertilizer. International Journal of Biology, 4, 60-65. https://doi.org/10.5539/ijb.v4n4p60

[40] Malav, J.K. and Ramani, V.P. (2016) Yield and Nutrient Content of Rice as Influenced by Silicon and Nitrogen Application. Research Journal of Chemistry and Environment Science, 4, 46-49.

[41] Yuan, J.C., Ding, Z.Y., Yao, F.J., Yu, X.P. and Luo, F.X. (2005) Effect of N, P, K, Fertilizer on $\mathrm{Fe}, \mathrm{Zn}, \mathrm{Cu}, \mathrm{Mn}, \mathrm{Ca}$, and $\mathrm{Mg}$ Contents and Yields in Rice. Chinese Journal of Rice Sciience, 19, 434-440.

[42] Omar, K.A., Salih, B.M., Abdulla, N.Y., Hussin, B.H. and Rassul, S.M. (2016) Evaluation of Starch and Sugar Content of Different Rice Samples and Study Their Physical Properties. Indian Journal of Natural Science, 6, 11084-11093. 
[43] Yadav, R.B., Khatkar, B.S. and Yadav, B.S. (2007) Morphological, Physicochemical and Cooking Properties of Some Indian Rice (Orya sativa L.) cultivars. Journal of Agricultural Technology, 3, 203-210.

[44] Nadiger, S. and Kasturiba, B. (2015) Nutritional Composition of Aromatic Rice Varieties. Karnataka Journal of Agricultural Science, 28, 580-582.

[45] Abeysekara, W.K.S.M., Somasiri, H.P.P.S., Premakumara, G.A.S., Bentota, A.P., Rajapaksha, D. and Ediraweera, N. (2008) Cooking \& Eating Quality Traits of Some Sri Lankan Traditional Rice Varieties across Yala \& Maha Seasons. Tropical Agriculture Research, 20, 168-176.

[46] Thumrongchote, D., Suzuki, T., Laohasongkram1, K. and Chaiwanichsiri, S. (2012) Properties of Non-Glutinous Thai Rice Flour: Effect of Rice Variety. Research Journal of Pharmaceutical Biological and Chemical Sciences, 3, 150-164.

[47] Li, H., Prakash, S., Nicholson, T.M., Fitzgerald, M.A. and Gilbert, R.G. (2016) The Importance of Amylose and Amylopectin Fine Structure for Textural Properties of Cooked Rice Grains. Food Chemistry, 196, 702-711.

[48] Samaraweera, U. (1999) Nutritional Quality of Rice. Economic Review, 17-22.

[49] Zhang, C., Zhou, L., Zhu, Z., Zhou, X., Qian, Y., Li, Q., Lu, Y., Gu, M. and Liu, Q. (2016) Characterization of Grain Quality and Starch Fine Structure of Two Japonica Rice (Oryza sativa) Cultivars with Good Sensory Properties at Different Temperatures during the Filling Storage. Agricultural and Food Chemistry, 64, 4048-4057.

[50] Megazyme (2016) Amylose/Amylopectin. Assay Procedure for Measurement of Amylose and Amylopectin of Starch. 11 p. http://www.megazyme.com

[51] Patindol, J., Wang, Y.J. and Jane, J. (2005) Structure-Functionality Changes in Starch Following Rough Rice Storage. Stasrch Stärke, 57, 197-207.

https://doi.org/10.1002/star.200400367

[52] Frei, M., Siddhuraju, P. and Becker, K. (2003) Studies on the in Vitro Starch Digestibility and the Glycemic Index of Six Different Indigenous Rice Cultivars from the Philippines. Food Chemistry, 83, 395-402.

[53] Edeogu, C.O., Ezeonu, F.C., Okaka, A.N.C., Ekuma, C.E. and EIom, S.O. (2007) Proximate Compositions of Staple Food Crops in Ebonyi State, South Eastern Nigeria. International Journal of Biotechnology and Biochemistry, 1, 1-8.

[54] Probart, C.K., Bird, P.J. and Parker, K.A. (1993) Diet and Athletic Performance. Medicine and Clinical Journal of North America, 5, 77-757.

[55] Eggum, B.O., Juliano, B.O. and Magningat, C.C. (1982) Protein and Energy Utilization of Rice Milling Fractions. Journal of Human Nutrition, 31, 371-376.

[56] Rivero, H., Mario, J., Raquel, H., Lorena, F., Liliana, V. and Elena, D. (2007) Concentration of As, $\mathrm{Ca}, \mathrm{Cd}, \mathrm{Cr}, \mathrm{Cu}, \mathrm{Fe}, \mathrm{Hg}, \mathrm{K}, \mathrm{Mg}, \mathrm{Mo}, \mathrm{Na}, \mathrm{N}, \mathrm{Pb}$ and $\mathrm{Zn}$ in Uruguayan Rice, Determined by AAS. Atomic Spectroscopy, 27, 48-55.

[57] Pederson, B. and Eggum, B.O. (1983) The Influence of Milling on the Nutritive Value of Flour from Cereal Grains. IV. Rice. Plant and foods for Human Nutrition, 33, 267-278. https://doi.org/10.1007/BF01094752

[58] Bourn, D. and Prescott, J.A. (2002) Comparison of the Nutritional Value, Sensory Qualities, and Food Safety of Organically and Conventionally Produced Foods. Critical Reviews in Food Science and Nutrition, 42, 1-34. https://doi.org/10.1080/10408690290825439

[59] Kennedy, G. and Burlingame, B. (2003) Analysis of Food Composition Data on Rice from a Plant Genetic Resources Perspective. Food Chemistry, 80, 589-596. 
Submit or recommend next manuscript to SCIRP and we will provide best service for you:

Accepting pre-submission inquiries through Email, Facebook, LinkedIn, Twitter, etc. A wide selection of journals (inclusive of 9 subjects, more than 200 journals)

Providing 24-hour high-quality service

User-friendly online submission system

Fair and swift peer-review system

Efficient typesetting and proofreading procedure

Display of the result of downloads and visits, as well as the number of cited articles Maximum dissemination of your research work

Submit your manuscript at: http://papersubmission.scirp.org/

Or contact fns@scirp.org 